\title{
PERBANDINGAN PENDAPATAN DAN PRODUKTIVITAS TENAGA KERJA \\ RUMAH TANGGA PETANI PEDESAAN DAN PERKOTAAN: Suatu Kasus Pada Agro Ekosistem Lahan Basah Berbasis Padi Sawah Di Kecamatan Tarogong Kaler Kabupaten Garut
}

\author{
Sudrajati Ratnaningtyas ${ }^{1}$ dan Wawan Purwana ${ }^{2}$ \\ 1) Universitas Winaya Mukti - Sumedang \\ e-mail : sratnaningtyas@yahoo.com \\ 2) Badan Pelaksana Penyuluhan Pertanian \\ Perikanan dan Kehutanan Kabupaten Garut
}

\begin{abstract}
ABSTRAK . Pembangunan yang dilakukan pemerintah tidak selalu merata hasilnya, baik dari sisi pandang antar sektor maupun antar wilayah. Masih banyak tenaga kerja yang menjadi beban sektor pertanian di pedesaan ataupun di perkotaan. Sektor industri tidak siap menampung surplus tenaga kerja yang berpindah dari sektor pertanian. Surplus tenaga kerja tersebut tidak dipersiapkan untuk memenuhi kriteria yang diperlukan oleh industri atau jasa yang terkonsentrasi di perkotaan. Penelitian ini menggunakan Explanatory Survey Method dan penarikan sampel dilakukan dengan menggunakan teknik Cluster Random Sampling. Ukuran sampel yang digunakan yaitu 26 rumah tangga untuk perkotaan dan 33 rumah tangga untuk pedesaan. Hasil penelitian ini menunjukkan bahwa rumah tangga petani di perkotaan lebih banyak ragam pekerjaan dan lebih tinggi pencurahan tenaga kerjanya dibandingkan dengan di pedesaan. Demikian pula dari sisi pendapatannya, namun dari sisi produktivitas tenaga kerja relatif sama. Hal tersebut disebabkan oleh peningkatan pendapatan di kota yang relatif sebanding dengan peningkatan curahan kerjanya, yang berarti tidak terjadinya peningkatan efisiensi penggunaan tenaga kerja. Baik di pedesaan maupun di perkotaan pangsa pendapatan agribisnis relatif sama yaitu di atas $80 \%$, yang berarti di kedua wilayah tersebut agribisnis masih menjadi sumber pendapatan dominan masyarakat petaninya.
\end{abstract}

Kata kunci : tenaga kerja, pendapatan, produktivitas, rumah tangga

\section{COMPARATIVE LABOR PRODUCTIVITY AND INCOME HOUSEHOLDS AND URBAN RURAL FARMERS: A Case In Agro-Based Ecosystem Wetland Rice In District Tarogong Kaler Garut}

\begin{abstract}
The development done by the government were not always wellspread, either from sectoral or interregional perspective. There's still many labor force which become a burden for agricultural sector. The industrial are not prepared to absorb the labor force surplus which leaves the agricultural sector. Those labor force surplus were unprepared to match the criteria needed by urbanconcentrated industrial or services. This study uses Explanatory Survey Method
\end{abstract}


and sampling was done by using the Cluster Random Sampling. The sample size used is 26 for urban households and 33 for rural household. This research shows that farm-hausehold in urban areas have more job variety and higher manhours compared with in rural areas. This is also the case from the income side, however from the labor force perspective it's relatively the same. It is caused by the increase of income in urban areas thats relatively comparable with the increase of manhours. That means the rise of labor force employment do not happen. Either in rural areas the share of agribusiness income relatively equal wich is over $80 \%$. That means in both areas, agribusiness still become the dominant source of income for its farmer society.

Key words : labor force, income, productivity, household

\section{PENDAHULUAN}

Kondisi perekonomian dan ketenagakerjaan di pedesaan di Indonesia secara kronologis sangatlah menarik untuk dicermati. Dari sanalah dapat ditengerai adanya perkembangan permasalahan perekonomian dan ketenagakerjaan dalam konteks desa-kota. Pada tiap tahap memiliki permasalahan sendiri-sendiri. Di jaman sebelum kemerdekaan, pembukaan perkebunan-perkebunan merupakan pemecahan yang baik untuk mengatasi pengangguran di pedesaan, karena mampu menyerap tenaga kerja dari desa sekitarnya. Inilah yang dinamakan oleh Clifford Geertz sebagai "industrialisasi tanpa urbanisasi". Pasca kemerdekaan, terjadi pengangguran kembali di desa-desa dikarenakan pembumihangusan perkebunan dan rusaknya pasar ekspor komoditas pertanian Indonesia (Mubyarto, 1982).

Sebagaimana disampaikan oleh Todaro dan Smith (2006) pembangunan ekonomi di Dunia Ketiga pasca Perang Dunia Kedua didominasi oleh empat teori klasik yang terkadang bersaing satu sama lain, yaitu : 1) Linear-stages-of growth models, 2) theories and patterns of structural change, 3) the international dependent revolution, 4) the neoclassical free-market counterrevolution.

Pada masa Orde Baru, pembangunan jangka panjang beserta Pelita-Pelitanya disusun berdasarkan teori Rostow. Keserasian pembangunan antar daerah dikembangkan Pemerintah Pusat berdasarkan pertimbangan sektoral, proyekproyek investasi diusahakan dapat memberikan pemerataan, pengaruh penyebaran pembangunan (spreading effect) bagi perekonomian daerah, yang memberikan dampak kepada perluasan kesempatan kerja, baik langsung maupun tidak langsung, dan bagi peningkatan produktivitas serta nilai tambah bagi perekonomian daerah (Rusli Galib , 2005).

Pasca Orde baru, model Rostow ditinggalkan dan sekarang ini pendekatan perekonomian Indonesia menggambarkan variasi dari keempat perspektif pendekatan pembangunan menurut Todaro dan Smith (2006) di atas. Ternyata hal inipun menimbulkan banyak permasalahan bagi ketenaga kerjaan di desa maupun kota di Indonesia. Menurut Iskandar Andi Nuhung (2006) data Bappenas tahun 2004 menunjukkan bahwa terdapat $32 \%$ tenaga kerja nasional yang ada di 
sektor pertanian berstatus disguise unemployment atau setengah menganggur yang menjadi beban sektor pertanian. Surplus tenaga kerja tersebut tidak dipersiapkan untuk memenuhi kriteria yang diperlukan oleh industri atau jasa yang terkonsentrasi di perkotaan. Hal ini mengindikasikan bahwa gejala pengangguran tidak kentara terjadi pada masyarakat petani di pedesaan maupun pada masyarakat petani di perkotaan.

Perubahan paradigma pembangunan pertanian dari pendekatan komoditas ke agribisnis salah satu tujuannya dalam rangka peningkatan pendapatan khususnya pendapatan rumah tangga petani. Pendapatan itu harus memberikan kelayakan bagi rumah tangga petani. Dengan rata-rata penguasaan lahan kurang dari 0,5 hektar maka petani sulit memperoleh pendapatan yang layak dari usahataninya. Namun anggota rumah tangga petani di samping usahatani umumnya juga mencari tambahan penghasilan dari usaha lainnya. Sebagaimana menurut Saragih (2010) sejalan dengan tahapan-tahapan perkembangan ekonomi, kegiatan jasajasa dan bisnis yang berbasis pertanian juga akan semakin meningkat, yaitu kegiatan agribisnis.

Simanjuntak (1985) menyatakan penciptaan kesempatan kerja menjadi fokus sentral dari rencana pembangunan ekonomi masyarakat kita. Masalahnya sekarang bagaimana kita mengetahui bahwa usaha ini telah berhasil, dan bagaimana cara mengukurnya. Cara pengukuran konvensional yaitu dengan menghitung jumlah orang yang berhasil mendapatkan pekerjaan. Memang jelas bahwa makin banyak orang yang bekerja makin kokoh basis pembagian masyarakat, tetapi masih perlu dipertanyakan tentang seberapa jauh intensitas pekerjaan yang dilaksanakan, berapa besar penghasilannya. Pertanyaan-pertanyaan yang perlu dijawab yaitu apakah rumah tangga petani di daerah yang telah berkembang menjadi kota mampu meningkatkan aktivitas kerjanya di sektor pertanian dan non pertanian dan juga pendapatannya lebih besar dibanding dengan rumah tangga petani yang ada di daerah pedesaan. Ataukah justru sebaliknya bahwa rumah tangga petani pedesaan mampu meningkatkan aktivitas dan pendapatannnya di bidang pertanian walaupun peluang kerja non pertaniannya terbatas. Pertanyaan-pertanyaan tersebut akan dapat diketahui jawabnya apabila dilakukan penelitian yang memperbandingkan curahan kerja, pendapatan, produktivitas tenaga kerja serta pangsa pendapatan agribisnis antara rumah tangga petani di perkotaan dengan pedesaan. Jawaban yang didapatkan akan dapat menjadi informasi bagi perumusan kebijakan oleh pihak-pihak yang berwenang

John Freedman dan Cleyde Wever dalam bukunya Territory and Function : The Evaluation of Regional Planning tahun 1979 (dalam Rusli Galib, 2005) membagi suatu wilayah atas Core dan Periphery. Core adalah pusat dari wilayah yaitu perkotaan, sedangkan Periphery adalah wilayah di sekitar core, yaitu hinterland atau pedesaan. Core merupakan lokasi pusat kegiatan atau lokasi pusat pertumbuhan kegiatan penduduk di suatu wilayah dalam semua aspek kehidupan, yang meliputi aspek-aspek sosial, politik, ekonomi dan kebudayaan. Ciri dari core yaitu: tingkat kepadatan penduduk relatif lebih tinggi, dan fasilitas pelayanan lebih 
lengkap. Jadi dapat disimpulkan bahwa suatu kota secara definitif sekurangkurangnya haruslah memenuhi tiga kriteria tersebut di atas, yaitu menyangkut : kepadatan penduduk, struktur pekerjaan penduduk, dan kondisi sarana dan prasarana pelayanan umum.

Menurut Sudrajati Ratnaningtyas (2006) agribisnis perlu dikembangkan dengan pendekatan sistem, yang meliputi empat subsistem utama yaitu subsistem agroinput, usahatani, penanganan dan pengolahan ( agroindustri), dan pemasaran, serta dua sistem pendukung yaitu subsistem sarana\& prasarana , serta subsistem pembinaan. Agroindustri memegang peran penting dalam sistem agribisnis, sebab agroindustri mampu memberikan nilai tambah kepada produk pertanian, membuka kesempatan kerja, meningkatkan pendapatan masyarakat dan negara, dan menjadi pemicu pertumbuhan ekonomi daerah.

Menurut Suseno Triyanto Widodo (1990), konsep labor force approach memang telah memberi indikator tentang masalah ketenagakerjaan, namun gambaran tersebut masih global dan kasar. Sebab dari penduduk yang sudah bekerja masih terdapat setengah menganggur kentara maupun tidak kentara. Setengah menganggur kentara memberi indikasi pemanfaatan yang belum optimal dari sumberdaya manusia, sedangkan setengah menganggur tak kentara memberikan indikasi rendahnya kualitas sumberdaya manusia karena produktivitas dan pendapatan mereka rendah. Dari konsep labor utilization approah, akan diperoleh gambaran lebih mendalam tentang keadaan ketenagakerjaan, sehingga analisis tentang potensi kemampuan penduduk lebih realistis. Menurut Vink (1984) rumah tangga petani adalah sekelompok sosial terkecil terdiri atas suami, istri, anak, serta keluarga dekat/jauh yang hidup bersama dan telah diperlakukan sama dalam keluarga.

Produktivitas mengandung pengertian filosofis, definisi kerja dan teknis operasional (Simanjuntak 1985). Menurut Hansen and Mowen (1999), produktivitas input tunggal biasanya diukur dengan menghitung rasio output terhadap input.

Dalam penelitian ini dicari kebenaran atas anggapan bahwa pembangunan pedesaan menjadi perkotaan akan mampu meningkatkan kesejahteraan masyarakat yaitu melalui peningkatan kesempatan kerja, pendapatan dan sekaligus produktivitas kerja rumah tangga petani yang ada pada wilayah tersebut. Tesis yang ada menyatakan bahwa pertumbuhan desa menjadi kota akan menyebabkan bertambahnya ragam dan intensitas kerja, yang lebih lanjut menyebabkan peningkatan curahan waktu kerja dan pendapatan masyarakat. Dalam penelitian ini secara serentak akan diukur dan diperbandingkan curahan kerja, pendapatan dan produktivitas kerja antara rumah tangga petani di pedesaan dengan di perkotaan untuk mengukur keberhasilan pembangunan pedesaan menjadi perkotaan. Lebih lanjut untuk mengetahui apakah petani mampu mengembangkan pertanian di perkotaan, maka dilakukan pembandingan pangsa pendapatan agribisnis dalam struktur pendapatan rumah tangga, antara petani di pedesaan dengan di perkotaan. 


\section{METODE}

Penelitian ini menggunakan explanatory survey method. Jenis penelitiannya adalah penelitian dekriptif kuantitatif. Unit elementer yang diteliti sebagai unit analisis adalah rumah tangga petani padi sawah yang ada pada dua daerah yaitu daerah perkotaan dan daerah pedesaan yang ada pada Kecamatan Tarogong Kaler Kabupaten Garut.

Definisi dan operasionalisasi variabel

1. Tenaga kerja rumah tangga petani yaitu istri dan suami, anak atau orang lain yang berumur 15 tahun ke atas yang melakukan pekerjaan untuk suatu tujuan yang bersifat ekonomis dan mendapat imbalan jasa. Curahan tenaga kerjanya diukur dalam jam kerja pria ( JKP) atau setara JKP (konversi curahan kerja wanita ke dalam JKP berdasarkan upah ).

2. Pendapatan total rumah tangga adalah penjumlahan dari usaha agribisnis dan pendapatan usaha non agribisnis diukur dalam rupiah per tahun.

3. Produktivitas tenaga kerja adalah pendapatan yang diperoleh tenaga kerja rumah tangga untuk setiap satuan curahan waktu kerja, yang dalam hal ini diukur dalam rupiah per JKP.

Sasaran populasi (population target) pada penelitian ini adalah rumah tangga petani agro ekosistem lahan basah berbasis padi di Kecamatan Tarogong Kaler. Penarikan sampel dilakukan dengan menggunakan teknik cluster random sampling (Moh. Nazir, 1988), dalam hal ini dilakukan dengan dua tahap (two stages cluster random sampling), yaitu desa sebagai primary unit sampling Rumah tangga petani sebagai secondary sampling unit. Ukuran sampel untuk perkotaan $=26$ rumah tangga (yang ada pada Desa Jati dan Ranca Bango) dan pedesaan = 33 rumah tangga (yang ada pada desa Mekar Jaya, Mekarwangi, Sirnajaya). Data primer diperoleh dari rumah tangga petani dengan tekhnik wawancara. Data primer berupa crossectional data yaitu data bulan Oktober 2008 sampai Oktober 2009. Penelitian lapangan dilakukan dari bulan Nopember 2009 sampai dengan Januari 2010.

Untuk menguji perbedaan, terlebih dahulu dilakukan uji normalitas distribusi data dengan uji Shapiro-Wilk. Dilanjutkan dengan uji homogenitas varians Levene test $(\mathrm{p}>0,05)$ untuk menentukan statistik uji yang akan digunakan untuk mengetahui perbedaan variabel penelitian antar kelompok apakah menggunakan uji t atau uji Mann-Whitney. Taraf nyata ( $a$ ) yang digunakan dalam pengujian adalah 0,05 .

\section{HASIL DAN PEMBAHASAN \\ Karakteristik Responden dan Rumah Tangga Petani}

Petani responden di perkotaan mayoritas berpendidikan SMP (50\%) sedangkan di pedesaan mayoritas berpendidikan SD (63\%). Pendidikan merupakan salah satu yang akan menentukan akses petani dalam meraih kesempatan kerja, khususnya pada sektor luar pertanian. Jumlah anggota keluarga petani di perkotaan mupun di pedesaan berkisar antara 1 sampai 6 
orang, dengan rata-rata 4,2 orang untuk perkotaan dan 4,6 untuk pedesaan. Ratarata lahan garapan petani di perkotaan sama dengan di pedesaan yaitu 0,44 $\mathrm{Ha}$. Petani responden di pedesaan dan perkotaan memiliki dua ragam bidang kerja atau lebih, yang berarti mereka mencari pendapatan bukan hanya dari usahatani namun juga usaha industri kecil atau rumah tangga.

Dalam rumah tangga petani (RTP) aktivitas kerja dilakukan oleh anggota rumah tangga yang merupakan satu kesatuan ekonomi. Curahan jam kerja terbanyak dilakukan oleh bapak kemudian ibu, diikuti anak dan anggota lainnya, baik dalam bidang agribisnis (on farm dan off farm) maupun di luar agribisnis, baik di perkotaan maupun di pedesaan.

Tabel 1. Rata-rata Curahan Waktu Kerja Rumah Tangga, Pendapatan Bersih, Produktivitas Kerja, dan Pangsa Pendapatan Agribisnis pada Rumah Tangga di Perkotaan dan Pedesaan

\begin{tabular}{lcc}
\hline Variabel & Per kuartal & Per tahun \\
\hline Curahan Waktu Kerja & & \\
$\quad$ Perkotaan & & \\
Pedesaan & $2.429,9$ & $7.289,7$ \\
Pendapatan Bersih (Rp) & $1.510,8$ & $4.532,4$ \\
$\quad$ Perkotaan & 12.906 .500 & 38.719 .500 \\
$\quad$ Pedesaan & 8.297 .300 & 24.891 .900 \\
Produktivitas Kerja (Rp/JKP) & & \\
$\quad$ Perkotaan & & $22.882,8$ \\
$\quad$ Pedesaan & & $14.074,9$ \\
Pangsa Pendapatan & & \\
Agribisnis (\%) & & 88,2 \\
$\quad$ Perkotaan & & 91,6 \\
Pedesaan & & \\
\hline
\end{tabular}

Keterangan : JKP = Jam Kerja Pria atau setara pria

Perbandingan Curahan Waktu Kerja, Pendapatan, Produktivitas, dan Pangsa Pendapatan Agribisnis antara Rumah Tangga Petani di Perkotaan dengan Rumah Tangga Petani di Pedesaan

Hasil uji normalitas pada Tabel 2. menunjukkan bahwa data penelitian pada keempat variabel penelitian untuk kelompok Perkotaan (KOTA) dan Pedesaan (DESA) tidak memenuhi asumsi normalitas $(p<0,05)$. Berdasarkan hasil uji normalitas data dan uji homogenitas data sebagaimana pada Tabel 2 dan 3, maka diputuskan untuk digunakan Uji Mann-Whitney untuk menguji perbedaan keempat variabel penelitian ini. 
Tabel 2. Hasil Uji Normalitas Distribusi Data Pencurahan Waktu Kerja RTP, Produktivitas Tenaga Kerja, Pendapatan RTP dan Pangsa Pendapatan Usaha Agrobisnis

\begin{tabular}{|c|c|c|c|c|}
\hline Uji Normalitas & Kelompok & Shapiro-Wilk & $\mathrm{db}$ & p \\
\hline \multirow[t]{2}{*}{ Pencurahan Waktu Kerja RTP } & KOTA & 0,799 & 26 & 0,000 \\
\hline & DESA & 0,864 & 33 & 0,001 \\
\hline Pendapatan RTP & KOTA & 0,798 & 26 & 0,000 \\
\hline Produktivitas Tenaga Kerja & $\begin{array}{l}\text { DESA } \\
\text { KOTA } \\
\text { DESA }\end{array}$ & $\begin{array}{l}0,852 \\
0,734 \\
0,855\end{array}$ & $\begin{array}{l}33 \\
26 \\
33\end{array}$ & $\begin{array}{l}0,000 \\
0,000 \\
0,000\end{array}$ \\
\hline \multirow[t]{2}{*}{ Pangsa Pendapatan Usaha Agribisnis } & DESA & 0,855 & 33 & 0,000 \\
\hline & DESA & 0,596 & 33 & 0,000 \\
\hline $\begin{array}{l}\mathrm{p} \leq 0,05==>\text { data } \\
\mathrm{p}>0,05==>\text { data } \\
\mathrm{p}=\text { signifikansi }(p-\end{array}$ & $\begin{array}{l}\text { erdistribusi n } \\
\text { tribusi norma }\end{array}$ & & & \\
\hline
\end{tabular}

Berdasarkan pengujian homogenitas data pada Tabel 3 terlihat bahwa data Pencurahan Waktu Kerja RTP dan Pendapatan Rumah tangga memiliki varians data yang homogen $(p>0,05)$. Sedangkan variabel penelitian Produktivitas Tenaga Kerja dan Kontribusi Pendapatan Usaha Tani RTP memiliki varians data yang tidak homogen.

Tabel 3. Hasil Uji Homogenitas Varians Data Pencurahan Waktu Kerja RTP, Produktivitas Tenaga Kerja, Pendapatan RTP dan Pangsa Pendapatan Usaha Agrobisnis

\begin{tabular}{llcc}
\hline \multicolumn{1}{c}{ Uji Homogenitas Varians } & Kelompok & Levene's test & $\mathrm{p}$ \\
\hline Pencurahan Waktu Kerja RTP & KOTA & 0,828 & 0,367 \\
& DESA & & \\
Pendapatan RTP & KOTA & 3,268 & 0,076 \\
& DESA & & \\
Produktivitas Tenaga Kerja & KOTA & 13,340 & 0,000 \\
& DESA & & \\
Pangsa Pendapatan Usaha Agribisnis & KOTA & 0,044 & 0,834 \\
& DESA & & \\
\hline
\end{tabular}

Keterangan: $\quad \mathrm{p} \leq 0,05==>$ data tidak homogen

$\mathrm{p}>0,05==>$ data homogen 
Hasil uji perbedaan pencurahan waktu kerja RTP antara Kota dengan Desa dapat dilihat pada Tabel 4.

Tabel 4. Hasil Uji Perbedaan Pencurahan Waktu Kerja RTP Antara di Pedesaan dan Perkotaan

\begin{tabular}{|c|c|c|c|c|c|c|}
\hline Variabel & Kelompok & $\mathrm{n}$ & $\bar{x}$ & sd & $z$ & $\mathrm{p}$ \\
\hline \multirow[t]{2}{*}{ Pencurahan Waktu Kerja RTP } & КOTA & 26 & 2429,9 & 1965,3 & $2, \overline{382}$ & 0,017 \\
\hline & DESA & 33 & 1510,8 & 1246,7 & & \\
\hline \multirow[t]{2}{*}{ Pendapatan RTP } & KOTA & 26 & $\begin{array}{r}12906, \\
5\end{array}$ & 6112,2 & $\overline{3,741}$ & 0,000 \\
\hline & DESA & 33 & 8297,3 & 3343,1 & & \\
\hline Produktivitas Tenaga Kerja & $\begin{array}{l}\text { KOTA } \\
\text { DESA }\end{array}$ & $\begin{array}{l}26 \\
33\end{array}$ & $\begin{array}{r}14074, \\
9 \\
22882 \\
8\end{array}$ & $\begin{array}{r}9965,3 \\
17050 \\
4\end{array}$ & $\begin{array}{c}- \\
1,695\end{array}$ & 0,090 \\
\hline \multirow{2}{*}{$\begin{array}{l}\text { Pangsa Pendapatan } \\
\text { Usaha Agrobisnis }\end{array}$} & КОТА & 26 & 88,2 & 14 & $\begin{array}{c}- \\
1,485\end{array}$ & 0,138 \\
\hline & DESA & 33 & 91,6 & 16,2 & & \\
\hline \multicolumn{2}{|c|}{$\begin{array}{ll}\text { Keterangan : } & \bar{x}=\text { rata-rata } \\
& \text { sd }=\text { standar deviasi }\end{array}$} & . & $=$ statis & uji Man & & \\
\hline
\end{tabular}

Berdasarkan hasil pengujian pada tabel di atas, nilai-p 0,017 lebih kecil dari $\alpha$ $=5 \%$, berarti terdapat perbedaan yang signifikan. Dengan kata lain rata-rata pencurahan waktu kerja rumah tangga petani perkotaan lebih besar dari pada rumah tangga petani pedesaan (1510,8 JKP/tahun).

Untuk variabel pendapatan, maka nilai $p=0,000$ yang lebih kecil dari $\alpha=$ 0.05 berarti terdapat perbedaan yang signifikan. Dengan kata lain rata-rata pendapatan rumah tangga petani di perkotaan (Rp 12.906,5/tahun) lebih besar dari rata-rata pendapatan rumah tangga petani pedesaan ( $R p$ 8.297,3/tahun).

Berdasarkan hasil pengujian pada Tabel 4, dengan nilai-p 0,090 yang lebih besar dari $\alpha=5 \%$, berarti produktivitas tenaga kerja rumah tangga di perkotaan berbeda secara tidak signifikan dengan di pedesaan. Produktivitas tenaga kerja pada rumah tangga petani di perkotaan sebesar Rp 14. 074,9/JKP dan di pedesaan sebesar Rp 22.882,8/JKP.

Hasil uji perbedaan pangsa pendapatan usaha agribisnis terhadap total pendapatan rumah tangga petani antara di perkotaan dengan di pedesaan menunjukkan nilai $p=0,138$ yang lebih besar dari $\alpha=0,05$ maka dapat disimpulkan terdapat perbedaan yang tidak signifikan. Nilai rata-rata pangsa pendapatan usaha agribisnis terhadap total pendapatan pada rumah tangga perkotaan sebesar $88,2 \%$ sedangkan untuk pedesaan $91,6 \%$. 


\section{Pembahasan}

Rata-rata curahan jam kerja RTP di perkotaan adalah $7.290 \mathrm{JKP} / \mathrm{th}$, dan ratarata jumlah tenaga kerja per RTP adalah 3,6 maka curahan kerja per orangnya adalah $42,5 \mathrm{JKP} / \mathrm{ming}$ gu. Di lain pihak pada RTP di pedesaan dengan rata-rata curahan kerja $4.532 \mathrm{JKP} /$ tahun dan jumlah tenaga kerja 3,5 maka curahan kerja per orangnya adalah $26,6 \mathrm{JKP} /$ minggu. Menurut standar BPS tenaga kerja disebut sebagai bekerja penuh bila bekerja lebih dari 35 jam per minggu. Jadi berdasarkan standar tersebut, tenaga kerja pada RTP perkotaan sudah termasuk dalam tenaga kerja yang bekerja penuh, sedangkan untuk RTP pedesaan masih termasuk dalam setengah menganggur. Dengan ragam pekerjaan umumnya 1 sampai 2 jenis untuk RTP perkotaan dan 2 sampai 3 jenis pekerjaan pada RTP pedesaan, ternyata angkatan kerja pada RTP telah mampu memberdayakan diri untuk bisa bekerja penuh. Terdapat selisih cukup banyak antara curahan jam kerja per minggu antara RTP perkotaan dan pedesaan. Hal ini seiring dengan hasil pengujian statistik yang menyimpulkan adanya perbedaan yang signifikan dalam hal pencurahan tenaga kerja ini.

Rata-rata pendapatan pada RTP perkotaan adalah Rp 38.719.500/th, dengan rata-rata jumlah anggota keluarga 4,3 maka pendapatan per kapitanya adalah Rp 8.908.910/th. Bila pada waktu penelitian ini nilai US dollar sekitar Rp 9.000,00 maka pendapatan per kapitanya sekitar \$990/th atau \$2,71/ hari. Bila menurut Bank Dunia digunakan standar kemiskinan adalah dibawah \$1/hari, maka RTP di perkotaan sudah berada di atas garis kemiskinan. Standar kemiskinan menurut Sayogjo yang menggunakan pendekatan pengeluaran per kapita setara beras tidak relevan digunakan di sini karena pendekatan penelitian ini berdasarkan pendapatan. Untuk RTP pedesaan, dengan rata-rata pendapatan RTP Rp 24.891.900/tahun, dengan rata-rata jumlah anggota keluarga 4,6 maka pendapatan per kapitanya adalah Rp 5.404.163/th, atau 1,64/hari, yang juga di atas standar kemiskinan. Aktivitas pada beragam pekerjaan oleh anggota RTP baik di perkotaan maupun di pedesaan telah mampu memberikan pendapatan sehingga mereka tergolong tidak miskin. Terdapat perbedaan yang cukup besar antara pendapatan RTP perkotaan dengan pedesaan. Hal tersebut juga seiring dengan hasil pengujian statistiknya bahwa terdapat perbedaan yang signifikan dalam hal pendapatan RTP ini.

Hasil perhitungan produktivitas tenaga kerja ternyata memberikan informasi yang lebih akurat berkenaan dengan pemberian penghargaan bagi angkatan kerja. Dalam hal ini tidak hanya diungkap status okupasi kerjanya, namun juga imbangan dengan imbalan kerjanya. Produktivitas kerja ini menjadi salah satu ukuran untuk menentukan status penganggur atau tidaknya seseorang. Sebagaimana menurut Sisdjiatmo Kusumosuwidho dalam Suseno Triyanto Widodo (1990), bahwa seseorang disebut setengah menganggur tidak tentara bila memiliki produktivitas rendah dan juga pendapatan rendah. Bisa terjadi kasus dimana produktivitas kerjanya tinggi (pendapatan per jam kerjanya tinggi) namun pendapatannya 
rendah (bisa dikarenakan okupasinya yang rendah), maka yang bersangkutan juga termasuk dalam golongan setengah penganggur tidak kentara (SPTK). Sebutan tersebut juga berlaku bagi yang pendapatannya cukup tinggi namun produktivitas kerjanya rendah. Pada penelitian ini produktivitas kerja RTP perkotaan adalah Rp 22.883/JKP dan untuk RTP pedesaan Rp14.075/JKP. Bila upah minimum industri di kota Garut besarannya sekitar Rp 1.000.000/bl dengan jam kerja $35 \mathrm{jam} / \mathrm{minggu}$ atau $140 \mathrm{jam} / \mathrm{bl}$, maka produktivitas kerjanya adalah Rp 7.143/ JKP. Bila angka tersebut digunakan sebagai pembanding, maka produktivitas RTP perkotaan maupun pedesaan pada penelitian ini sudah jauh diatas angka pembanding tersebut. Dalam konteks pembandingan produktivitas RTP perkotaan dengan RTP pedesaan, pembandingan dilakukan atas data random bukan data exact, oleh karena itu harus melalui pengujian statistik. Dari hasil pengujian statistik ternyata perbedaan antara produktivitas RTP perkotaan dengan pedesaan adalah tidak signifikan, atau perbedaannya tidak bermakna. Dalam kata sehari-hari dapat dikatakan sebagai relatif sama. Hal ini dapat diartikan bahwa laju peningkatan pencurahan kerja di perkotaan dibandingkan dengan di pedesaan ternyata relatif sama dengan laju pertambahan pendapatannya.

Peran agribisnis masih sangat dominan dalam struktur pendapatan RTP perkotaan maupun pedesaan. Hal tersebut terlihat dari besaran pangsa pendapatan agribisnis yang diatas $80 \%$, yaitu untuk RTP perkotaan $91,6 \%$ dan pada RTP pedesaan $88,2 \%$. Berdasarkan pembahasan di atas, maka secara keseluruhan dapat disimpulkan bahwa angkatan kerja yang ada pada RTP perkotaan maupun pedesaan telah tergolong pada pekerja penuh (full employee) dengan pendapatan yang diatas garis kemiskinan, dan juga telah memanfaatkan tenaganya secara relatif produktif, dengan bidang kerja utamanya pada agribisnis. Dengan kata lain, agribisnis di pedesaan maupun di perkotaan mampu menyejahterakan masyarakat petani, walaupun secara normatif harus terus ditingkatkan.

\section{SIMPULAN}

Berdasarkan hasil penelitian maka dapat ditarik kesimpulan sebagai berikut :

1. Pencurahan waktu kerja rumah tangga petani perkotaan lebih besar daripada rumah tangga petani pedesaan. Besarnya pencurahan waktu kerja di perkotaan $2.430 \mathrm{JKP} /$ kuartal atau $7.290 \mathrm{JKP} /$ th dan di pedesaan 1.511 $\mathrm{JKP} /$ kuartal atau $4.533 \mathrm{JKP} /$ th.

2. Rata-rata pendapatan rumah tangga petani perkotaan lebih besar daripada rumah tangga petani pedesaan. Besarnya pendapatan petani di perkotaan Rp. 12.906.500/kuartal atau Rp 38.719.500 / tahun dan di pedesaan Rp. 8.297.300/ kuartal atau Rp 24.891.900 per tahun.

3. Rata-rata produktivitas tenaga kerja di perkotaan Rp. 14.075/JKP dan di pedesaan Rp. 22.883/JKP. Hasil uji statistik terhadap produktivitas tenaga kerja antara rumah tangga petani perkotaan dengan rumah tangga petani pedesaan tersebut nonsignifikan. Hal ini dapat diartikan bahwa laju 
peningkatan pencurahan kerja di perkotaan dibandingkan dengan di pedesaan ternyata relatif sama dengan laju pertambahan pendapatannya.

4. Pangsa pendapatan agribisnis terhadap pendapatan total rumah tangga petani perkotaan dengan pedesaan nonsignifikan. Besarnya kontribusi di perkotaan $88,2 \%$ dan di pedesaan $91,6 \%$, yang dapat diartikan bahwa agribisnis masih menjadi sumber pendapatan dominan bagi rumah tangga petani.

\section{DAFTAR PUSTAKA}

Galib, Rusli. 2005. Ekonomi Regional. Bandung. Pustaka Ramadhan.

Hanafie, Rita. 2010. Pengantar Ekonomi Pertanian. Yogyakarta: Penerbit Andi.

Hansen, Don R dan Maryanne M. Mowen. 1999. Akutansi Manajemen - Jilid I. diterjemahkan oleh : Ancella A. Hermawan. Jakarta : Penerbit Erlangga.

Nazir, Moh. 1988. Metode Penelitian. Jakarta: Ghalia Indonesia.

Notohadikusumo, Tejoyuwono. 2006. Urbanisasi dan Pemajuan Pertanian. Revitalisasi Pertanian dan Dialog Peradaban. Jakarta: Penerbit Buku Kompas : 428-435. Editor : Jusuf Sutanto dan Tim.

Nuhung, Iskandar Andi. 2006. Bedah Terapi Pertanian Nasional : Peran Strategis dan Revitalisasi. Jakarta : PT Bhuana Ilmu Populer, Kelompok Gramedia.

Mangkuprawira. Sjafri 2008. Posisi Ilmu Manajemen Mutu Sumberdaya Manusia Dalam Pembangunan. Pemikiran Guru Besar Institut Pertanian Bogor : Perspektif Ilmu-Ilmu Pertanian dalam Pembangunan Nasional. Penyunting : Tridoyo Kusumastanto dan Tim. Jakarta : Penebar Swadaya : 595-599.

Mubyarto. 1982. Pengantar Ekonomi Pertanian. Jakarta: LP3ES.

Ratnaningtyas, Sudrajati. 2006. Pengembangan Sistem Agribisnis Kaitannya Dengan Demokrasi Ekonomi. Prosiding Seminar Nasional Kopwil IV. Vol.2, No.1, 19 April 2006: 103-109. Bandung: Kopertis Wilayah IV Jawa Barat dan Banten.

Saragih, Bungaran. 2010. Agribisnis Paradigma Baru Pembangunan Ekonomi Berbasis Pertanian. Bogor: PT Penerbit IPB Press.

Simanjuntak, Payaman J. 1989. Kebijaksanaan Ketenagakerjaan Dalam Pelita V, dalam Transformasi Tenaga Kerja Mencari Pilihan. Prisma No.5 Tahun XVIII, Jakarta: LP3ES. 
Soekartawi. 1993. Prinsip-Prinsip Dasar Ekonomi Pertanian Teori dan Aplikasi. PT. Raya Gapindo Persada Raya, Jakarta.

Widodo, Suseno Triyanto. 1990. Indikator Ekonomi, dasar Perhitungan Perekonomian Indonesia. Yogyakarta : Penerbit Kanisius.

Todaro, Michael P. dan Stephen C. Smith. 2006. Pembangunan Ekonomi. Jilid 1, Edisi Kesembilan. Penerjemah : Haris Munandar. Jakarta : Penerbit Erlangga.

Vink, Gerald Julian. 1984. Dasar-Dasar Usahatani Di Indonesia. Jakarta : Yayasan Obor Indonesia. 